\title{
MENGIDENTIFIKASI JENIS TUMBUHAN MELALUI METODE INQUIRY LEARNING PADA PEMBELAJARAN TEMATIK SATU SEKOLAH DASAR
}

\author{
Ferdian Achsani \\ Tadris Bahasa Indonesia \\ Institut Agama Islam Negeri Surakarta \\ Pos-el: dwikurniawan219@gm ail.com
}

\begin{abstract}
Inquiry Learning is a learning method that can be used to help active students in teaching and learning activities. So far, we know that teaching and learning activities are always centered on teachers and students as objects. This must be changed. Teachers must utilize learning methods that invite students to be active, creative and critical during the learning process. This research is included in descriptive qualitative research, by describing the application of learning methods and student writing results through the application of the method. This research was conducted at SD N 2. Create a data sample of 21 students in grade 6. Data collection techniques were using documentation techniques and reading techniques. The teacher documents the things that students do and reads the results of observations written by students. Data analysis techniques use interactive techniques, which include the process of collecting data, reducing data, displaying data and drawing conclusions. The results of this study concluded that in the application of this learning method the average results can be said to be good. This is seen from the number of average values which amounted to 72.61 .
\end{abstract}

Keywords:, Inquiry, Evaluation, Writing, Application, Results

\begin{abstract}
Abstrak
Inquiry Learning merupakan suatu metode pembelajaran yang dapat digunakan untuk membantu siswa aktif dalam kegiatan belajar mengajar. Selama ini kita ketahui bahwa kegiatan belajar mengajar selalu berpusat pada guru dan siswa sebagai objek. Hal ini harus diubah. Guru harus memanfaatkan metode pembelajaran yang mengajak siswa untuk aktif, kreatif dan kritis selama proses pembelajaran. Penelitian ini termasuk dalam penelitian deskriptif kualitatif, dengan mendeskripsikan penerapan metode pembelajaran dan hasil tulisan siswa melalui penerapan metode tersebut. penelitian ini dilakukan di SD N 2 Cangakan dengan jumalh sampel data 21 siswa kelas 6. Teknik pengumpulan data dengan te knik dokumentasi dan teknik baca. Guru mendokumentasikan hal-hal yang diperbuat siswa dan membaca hasil pengamatan yang telah ditulis siswa. Teknik analisis data menggunakan teknik interaktif, yang meliputi proses pengumpulan data, reduksi data, display data dan penarikan kesimpulan. Hasil penelitian ini menyimpulkan bahwa dalam penerapan metode pembelajaran ini hasil rata-rata dapat dikatakan baik. Hal in iterlihat dari jumlah nilai rata-rata yang berjumlah 72.61 .
\end{abstract}

Kata Kunci,: Inquiry, Evaluasi, Menulis, Penerapan, Hasil 


\section{4 | Ferdian Achsani}

\section{PENDAHULUAN}

Pembelajaran merupakan salah bentuk transfer ilmu pengetahuan dari guru atau pendidik kepada peserta didik. Dalam kegiatan pembelajaran dikenal dengan istilah belajar mengajar. Kegiatan ini merupakan salah satu sarana yang dilakukan guna mewujudkan cita-cita bangsa, sebagaimana yang diungkapkan oleh Aqillah dan Ifa (2018:41) bahwa pembelajaran juga bertujuan untuk mencerdaskan kehidupan bangsa dan membentuk ketrampilan dan nilai-nilai positif pada diri siswa. Namun sayangnya dalam kegiatan belajar mengajar saat ini masih sering ditemukan pembelajaran yang hanya berpusat pada guru. Siswa kurang diajak untuk berpikir kreatif atau mengeksplor kemampuan siswa. Guru kurang kreatif dalam menghidupkan suasana kelas, sehingga yang terjadi pembelajaran menjadi kurang hidup. Padahal, guru sebagai pemimpin yang bertanggung jawab harus dapat membangkitkan semangat siswa baik ketika proses pembelajaran berlangusng ataupun di luar proses pembelajaran (Purwanti, 2017).

Pada kurikulum K13 kini pembelajaran harus diarahkan pada lima komponen yaitu mengamati, menanya, mengumpulkan data, mengasosiasi menyampaikan. Dari kegiatan pembelajaran tersebut, siswa harus diajak kreatif untuk mengembangkan potensi diri dengan dibantu bimbingan dari guru. Selama ini dalam kegiatan pembelajaran peserta didik hanya dijadikan objek untuk mendengarkan guru berpidato di depan kelas. Hal ini sesuai dengan yang disampaikan oleh Devi, Yusak dan Widyamike (2018:104) bahwa dalam proses pebelajaran siswa tidak harus diberi pengetahuan melalui pidato guru di depan kelas akan tetapi siswa juga harus mampu menemukan sendiri hal yang baru. Akibatnya mudah sekali peserta didik merasa bosan dengan materi yan diberikan oleh guru. Sehingga hasil yang diperoleh peserta didik tidak paham dengan materi yang disampaikan oleh guru.jika hal yang demikian diulang tanpa adanya pembenahan maka dapat mematikan peserta didik. Untuk itu kehadiran kurikulum K13 hadir sebagai bentuk kurikulum untuk membenahi sistem pembelajaran yang telah membudidaya tersebut.

Metode pembelajaran Inquiry Learning merupakan salah satu metode pengajaran yang memusatkan perhatian pada murid agar aktif dalam kegiatan belajar mengajar. Metode Inquiry Learning dapat dijadikan salah satu metode pengajaran yang dilakukan oleh guru pada proses pembelajaran. Pada metode ini siswa harus aktif, kreatif dalam menemukan sendiri jawaban dari pertanyaan yang diberikan oleh guru melalui pengetahuan yang telah mereka dapatkan (Hanafiah \& Suhana, 2010:78). Karena sifatnya yang merangsang peserta didik untuk belajar, sehingga guru dapat

PiJIES: Pedagogik Journal of Islamic Elementary School 
menerapkannya untuk memicu siswa agar berperan aktif selama proses pembelajaran (Saharsa \& Muhammad, Qaddafi., 2018:59). Siswa harus mampu dalam memecahkan soal-soal yang diberikan oleh guru kepada peserta didik secara mandiri. Dalam penerapan metode ini, guru bertindak sebagai fasilitator untuk menunjang keberhasilan pembelajaran. Dengan memanfaatkan lingkungan sebagai sumber pembelajaran, hasil akhir yang dapat diperoleh melalui penerapan metode ini, siswa mampu secara mandiri dalam menyelesaikan soal-soal melalui pengalaman pembelajaran tersebut dan diharapkan dapat membentuk ranah kognitif siswa serta mendapatkan pengetahuan baru melalui pengalaman pemelajaran yang sudah dilalui oleh siswa.

Metode ini mengharuskan siswa agar peserta didik memperoleh pengalaman belajar yang lebih realistik (nyata). Selain itu, metode ini juga mengajak siswa untuk berpikir lebih dalam dan kritis Siswa diminta untuk menemukan suatu persoalan yang baru dengan usaha sendiri, tentunya dengan bimbingan dari guru. Untuk mendapatkan hasil yang maksimal, dalam penerapan metode ini, guru harus mempersiapkan segala peralatan dan permasalahan yang nantinya akan dipecahkan oleh peserta didik.

Penerapan metode pembelajaran berbasis pertanyaan pada siswa kelas 6 di SD negeri 2 Cangakan ini memanfaatkan lingkungan sekolah sebagai objek yang diidentifikasi. Pada pembelajaran tematik satu, dimana siswa harus diajarkan materi IPA tentang tumbuhan dapat digabungkan dengan pembelajaran bahasa Indonesia. Sebagaimana yang telah kita ketahui bahwa pembelajaran pada jenjang sekolah dasar telah tersusun ke dalam sub tematik yang mana dalam setiap tematik memiliki perbedaan materi. Pembelajaran tematik merupakan pembelajaran yang berdasarkan bahwa pembelajaran harus memiliki relevan atau hubungan dengan pembelajaran yang lain. Sistem pembelajaran tematik tidak harus bergantung pada buku pelajaran yang telah tersedia, namun guru juga dapat menyusun sendiri materi pembelajaran (Antari, 2015:23). Begitu juga dengan pembelajaran yang dilakukan pada tema satu di SD negeri 2 Cangakan ini, pembelajaran dilakukan dengan mengindentifikasi manfaat dan jenis tumbuhan (IPA) kemudian menuliskannya dalam bentuk deskripsi (bahasa Indonesia), yang dalam buku pemerintah tidak ditersedia materi pembelajaran tersebut. tetapi dalam buku tertuliskan bahwa pembelajaran dapat dilakukan dengan meminta siswa untuk megidentifikasi atau mendeskripsikan tumbuhan. Adanya pembelajaran ini merupakan bentuk pengembangan dari soal tersebut agar siswa lebih kreatif dan kristis menghadapi permasalahan.

Pertanyaan yang diberikan kepada siswa pada pembelajaran ini adalah mengidentifikasi jenis-jenis tumbuhan yang hidup di sekitar lingkungan sekolah. siswa diminta untuk menemukan jenis-jenis tumbuhan 
dikotil dan monokotil yang berada di lingkungan sekitar sekolah. Dengan memanfaatkan lingkungan sekolah, siswa diajak untuk mengumpulkan informasi terkait jenis-jenis tumbuhan yang hidup di sekitar lingkungan sekolah. Siswa diajak keluar untuk mengamati lingkungan, agar pembelajaran tidak terkesan membosankan di dalam kelas. Selain itu, memperkenalkan siswa pada dunia nyata di halaman sekolah, menjadikan siswa lebih aktif dan memiliki banyak pengalaman nyata.

Pada tahap selanjutnya dalam pembelajaran ini, siswa tidak hanya diajak untuk berpikir kreatif dan mengenal lingkungan sekolah. Namun siswa juga dilatih dalam keterampilan menulis. Sudiharto (2017:85) mengungkapkan bahwa keterampilan siswa sekolah dasar ketika menuangkan ide-idenya dalam bentuk tulisan belum dapat dikatakan sempurna. Penyebabnya karena siswa kurang percaya diri terhadap kemampuan individu. Adanya metode pembelajaran dengan menerapkan metode ini juga diharapkan dapat menumbuhkan rasa percaya diri siswa. Selain karen rasa percaya diri siswa, tidak dapat dipungkiri bahwa guru juga dapat menjadi salah satu penyebab siswa kurang kreatif dalam menulis. Berdasarkan penelitian yang dilakukan oleh Hariyanto (2018) bahwa dalam tulisan guru SD, 45,17\% kalimat yang digunakan merupakan kalimat efektif dan 54,83\% kalimat tidak efektif, sehingga hal tersebut juga dapat menjadi penyebab bahwa keterampilan menulis siwa belum dapat dikatakan sempurna.

Keterampilan menulis merupakan keterampilan berbahasa yang paling sulit. Sebagaimana wawancara yang dilakukan oleh Siregar (2018:286) pada siswa kelas XI P2 SMK Negeri 1 Singaraja mengatakan bahwa kesulitan dalam menulis yaitu pada ide yang susah didapatkan dan susah diekspresikan menjadi tulisan yang tulisan yang runtut dan berkesinambungan. Selain itu kemampuan berbahasa siswa juga menjadi factor penyebab kesulitan dalam menulis. Sukardi (2018:34) mengungkapkan bahwa pembelajaran menulis dapat meningkatkan keterampilan siswa, meningkatkan kecerdasan emosional, intelektual, dan sosial, sehingga menulis merupakan titik tertinggi kemampuan berbahasa seseorang. Dalam pembelajaran ini siswa atau penulis diminta untuk menuliskan gagasan dalam bentuk tulisan, dengan tata bahasa yang harus sesuai dengan kaidah kebahasaan. Selain itu keterampilan menulis juga menjadi salah satu keterampilan berbahasa yang nantinya akan menghasilkan produk berupa bacaan. Sehingga dalam menulis, penulis halus jeli dan sebisa mungkin mengurangi kesalahan-kesalahan berbahasa.

Penerapan metode pembelajaran berbasis pertanyaan dengan produk hasil akhir berupa hasil karya tulis ini tidak hanya sekedar mengajak siswa PiJIES: Pedagogik Journal of Islamic Elementary School 
mengkritisi permasalahan berupa deskripsi tumbuhan. Tetapi siswa juga diajak lebih kritis dalam berbahasa, dengan harapan dapat menjadikan siswa lebih aktif dan kritis. Melalui kegiatan menulis, dapat menjadi bekal awal siswa dalam keterampilan menulis, sebelum measuki jenjang sekolah yang lebih tinggi. Dengan demikian, kegiatan menulis pada pembelajaran ini diharapkan menjadi latihan bagi siswa dalam menuangkan gagasan. Keterampilan menulis memerlukan banyak latihan agar tulisan mampu menjadi sempurna (Oktaria, Andayani, \& Kundharu, 2017:169). Untuk itu perlunya latihan sejak dini kegiatan menulis perlu dilakukan agar siswa mampu menguasi keterampilan berbahasa menulis.

Perlunya kegiatan evaluasi dalam pembelajaran bertujuan untuk mengukur sampai sejauh mana kemampuan siswa dalam menerima pembelajaran. Setiap mata pelajaran selalu melakukan kegiatan ini. adanya kegiatan evaluasi pada hasil siswa dapat dijadikan patokan bagi guru untuk mengukur kemampuan siswa selama proses menerima materi pembelajaran. Dalam hasil menulis, kegiatan penilaian dapat mengacu pada pendapat Amran ( dalam Mulyati, dkk, 2018) yang mengatakan bahwa lima komponen yang harus ada dalam tulisan di antaranya: isi karangan, bentuk karangan, tata bahasa, gaya penulisan, ejaan dan tanda baca. Kelima komponen tersebut menjadi aspek penilaian dalam pembelajaran ini.

Dari uraian tersebut maka penelitian ini bertujuan untuk mendeskripsikan penerapan dan hasil dari penerapan metode pembelajaran Inquiry Learning dalam pembelajaran tematik satu di SD negeri 2 Cangakan. Penelitian sebelumnya dan hampir serupa pernah dilakukan oleh Hasanah, Ferdian dan Afrizal. Dengan menerapkan metode Berpikir Kreatif Cara Spiritualisme Kritis yang digagas oleh ayu utami, menyimpulkan bahwa penerapan metode tersebut berpengaruh baik dalam mengembangkan keterampilan menulis cerpen mahasiswa Tadris bahasa Indonesia IAIN Surakarta (Hasanah, Ferdian, \& Afrizal, 2019). Berbeda dengan penelitian sebelumnya, yang menerapkan metode Berpikir Kreatif Cara Spiritualisme Kritis untuk meningkatkan keterampilan menulis cerpen, pada penelitian ini peneliti menerapkan metode Inquiry Learning dalam pembelajaran tematik di sekolah dasar. Perbedaan jelas terlihat pada penggunaan metode yang diterapkan dalam kegiatan menulis dan hasil tulisan yang diperoleh. Persamaan terdapat pada bagaimana hasil penerapan metode untuk meningkatkan keterampilan menulis.

Penelitian ini juga jauh berbeda dengan yang dilakukan oleh Patmawati (2018). Meskipun sama-sama menerapkan metode pembelajaran pada materi teks deskripsi, namun penggunaan metode, objek, dan sampel data dalam penelitian ini berbeda. Patmawati menerapkan penggunaan Metode Experiential Learning bagi mahasiswa Pendidikan Guru Sekolah 
Dasar. Hasil dari menerapan metode experiential learning sangat efektif digunakan dalam pembelajaran keterampilan menulis deskriptif pada mahasiswa PGSD pokjar Barra. Sedangkan pada penelitian ini menerapkan metode pembelajaran Inquiry learning bagi siswa kelas 6 SD.

\section{METODE}

Penelitian ini adalah penelitian deskriptif, dengan menguraikan dari hasil hasil pengamatan dokumentasi dan hasil belajar siswa. Data yang telah diperoleh dianalisis secara kualitatif serta diuraikan dalam bentuk deskriptif. Data yang dianalisis di dalamnya berbentuk deskriptif bukan berupa angka-angka kuantitatif. Namun dalam penelitian ini menggunakan angka-angka yang digunakan untuk menjabarkan hasil nilai siswa dalam setiap aspek. penelitian kualitatif mengungkap fenomena-fenomena pada suatu objek yang diteliti secara mendalam.

Tempat penelitian yaitu di SD negeri 2 Cangakan, Karanganyar, dengan sampel data sejumlah 21 siswa kelas 6. Waktu penelitian ini dilaksanakan pada bulan Juli tahun 2018. Pengumpulan data dilakukan dengan mendokumentasikan hal-hal yang dilakukan ketika pembelajaran berlangsung dan membaca hasil karangan siswa. Teknik analisis data menggunakan teori interaktif yang meliputi tahap pengumpulan data, reduksi data, penyajian data dan kesimpulan. Pada tahap pengumpulan data, peneliti melakukan kegiatan pembelajaran. Pada tahap reduksi data, peneliti melakukan pemilihan data yang telah terkumpul. Data yang telah terkumpul tersebut selanjutnya disajikan pada tahap display data dan langkah yang terakhir adalah penarikan kesimpulan. Adapun uraian yang dijelaskan dalam penelitian ini adalah hasil penilaian yang telah dihitung melalui rumus berikut ini.

Keterangan:

$$
M=\frac{\sum F X}{N}
$$

$$
\begin{aligned}
& \mathrm{M}=\text { Rata-rata } \\
& \mathrm{F}=\text { Frekuensi } \\
& \mathrm{X}=\text { Nilai akhir } \\
& \mathrm{N}=\text { jumlah siswa }
\end{aligned}
$$

Melalui rumus tersebut, karangan siswa dinilai berdasar lima aspek yang telah dikemukakan oleh Nurgiyantoro. Setiap aspek kategori memiliki nilai max 4 dan minimal 1 . Hasil penilaian dari setiap aspek dihitung dan total dibagi 2 dikali sepuluh. Kategori kriteria penilaian dalam penulisan deskripsi siswa dapat dilihat dalam tabel berikut ini. 
Tabel 1. Kategori Penilaian

\begin{tabular}{|l|l|}
\hline \multicolumn{1}{|c|}{ Kategori } & \multicolumn{1}{c|}{ Nilai } \\
\hline sangat baik & $86-100(3.51-4.00)$ \\
\hline baik & $71-85(3.01-3.50)$ \\
\hline cukup & $56-70(2.01-3.00)$ \\
\hline perlu bimbingan & $<55(1.01-2.00)$ \\
\hline
\end{tabular}

\section{PENERAPAN METODE INQUIRY LEARNING}

Sebelum Pembelajaran dengan menerapkan metode Inquiry Learning ini, peneliti telah melakukan beberapa kali pertemuan. Dalam setiap pertemuan tersebut, peneliti bertindak sebagai subjek yang selalu di depan dan berpidato untuk menyampaikan materi di depan kelas. Setelah setiap materi yang disampaikan kepada siswa telah selesai dilakukan, peneliti memberikan soal pembelajaran kepada siswa. Dari pembelajaran yang berlangsung demikian, peneliti ingin merubah suasana pembelajaran, salah satu dengan penerapan metode Inquiry Learning. Dalam penerapan metode ini, peneliti meminta siswa untuk keluar kelas, mengamati tumbuhtumbuhan di sekitar lingkungsan sekolah dan memilih salah satu jenis tumbuhan dikotil dan monokotil kemudian mendeskripsikan ciri-ciri, manfaat, serta cara perkembang biakan tumbuhan tersebut ke dalam bentuk tulisan atau karangan deskripsi ilmiah. Adapun langkah kegiatan pembelajaran ini dapat dilihat pada tabel berikut ini.

Tabel 2. Kegiatan pembelajaran

\begin{tabular}{|c|l|}
\hline Aspek & \multicolumn{1}{|c|}{ Kegiatan } \\
\hline Stimulasi & $\begin{array}{l}\text { A. Mengamati } \\
\text { Peserta didik mengamati tanaman yang tumbuh di sekitar } \\
\text { lingkungan sekolah }\end{array}$ \\
\hline $\begin{array}{c}\text { B. Menanya } \\
\text { Masalah }\end{array}$ & $\begin{array}{l}\text { Peserta didik merumuskan pertanyaan tentang jenis } \\
\text { tanaman, manfaat, cara berkembang biak. }\end{array}$ \\
\hline $\begin{array}{c}\text { Pengumpulan } \\
\text { Data }\end{array}$ & $\begin{array}{l}\text { C. Mengumpulkan Data } \\
\text { dari pertanyaan yang telah di susun oleh peserta didik, } \\
\text { selanjutnya peserta didik mengumpulkan data atau jawaban } \\
\text { dari pertanyaan yang telah disusun. }\end{array}$ \\
\hline
\end{tabular}




\begin{tabular}{|c|l|}
\hline $\begin{array}{c}\text { Pengolahan } \\
\text { Data }\end{array}$ & $\begin{array}{l}\text { D. Mengasosiasi } \\
\text { Peserta didik menghubungkan data yang telah ditemukan } \\
\text { dengan pengetahuan yang telah dimilikinya }\end{array}$ \\
\hline Pembuktian & $\begin{array}{l}\text { E. Mengomunikasikan } \\
\text { Peserta didik menyampaikan hasil temuannya } \\
\text { mengenai pertanyaan yang telah disusun dalam bentuk } \\
\text { karangan deskripsi. }\end{array}$ \\
\hline $\begin{array}{c}\text { Menarik } \\
\text { Kesimpulan }\end{array}$ & $\begin{array}{l}\text { Peserta didik menyimpulkan teks deskripsi yang telah } \\
\text { disusun dengan dibantu penguatan dari guru }\end{array}$ \\
\hline
\end{tabular}

Tabel di atas merupakan alur kegiatan pembelajaran yang dilakukan oleh guru dalam penerapan Inquiry Learning. Pendekatan yang dilakukan dalam pembelajaran ini menggunakan saintifik, sehingga kegiatan $5 \mathrm{M}$ (mengamati, menanya, mengumpulkan data, mengolah dan mengomunikasikan) tertera pada tabel di atas.

Kegiatan awal dimulai dengan kegiatan mengamati. Kegiatan mengamati merupakan kegiatan yang mengajak siswa untuk lebih jeli dalam melihat ataupun memahami hal-hal yang akan dibahas. Pada kegiatan ini siswa dibebaskan untuk memilih tumbuhan yang berada disekitar lingkungan sekolah, dengan ketentuan harus memilih satu tumbuhan dikotil dan satu tumbuhan monokotil. Harapannya, siswa nantinya dapat membedakan jenis-jenis tumbuhan dikotil dan monokotil secara nyata.

Setelah tahap mengamati selesai dilakukan, siswa menyusun pertanyaan-pertanyaan yang nantinya akan menjadi kerangka dalam membuat suatu paragraph deskripsi. Pertanyaan-pertanyaan tersebut berkaitan dengan hal-hal yang telah mereka amati. Pada tahapan ini siswa harus jeli dalam menyusun kerangka pertanyaan, sebab pada tahapan ini akan menentukan alur karangan deskripsi. Dari pertanyaan yang telah disusun, nantinya akan ditemukan jawabannya dan kemudian dirangkai menjadi paragraph yang padu.

Pada tahapan ketiga adalah tahap mengumpulkan informasi. Pertanyaan-pertanyaan yang telah disusun pada tahapan ini, siswa mulai mencarikan jawaban-jawabannya. Siswa boleh mencari jawaban tersebut melalui membaca buku-buku di perpustakaan ataupun menemukan jawaban berdasarkan pengalaman. Siswa dilarang bertanya kepada guru, karena dalam pembelajaran ini siswa yang harus bergerak aktif untuk mengumpulkan informasi. Informasi ataupun jawaban yang diperoleh siswa harus lengkap, tepat dan akurat, sebab selain pada tahapan kedua, pada tahapan ketiga ini juga menjadi penentu keberhasilan karangan deskripsi.

Tahap mengasosiasi adalah tahapan keempat, di mana siswa atau peserta didik harus menghubungkan temuan data yang telah diperoleh ke dalam bentuk uraian jawaban. Pada tahapan ini siswa harus sudah memikirkan kerangka teks deskripsi yang akan dibuat. Peserta didik harus

PiJIES: Pedagogik Journal of Islamic Elementary School 
mampu menyimpulkan jawaban berdasarkan gagasan yang telah mereka dapat melalui pembacaan buku ataupun pengalaman.

Tahapan terakhir adalah mengomunikasikan. Pada tahap ini siswa mulai menyusun seluruh data yang sudah dikumpulkan pada tahap-tahap sebelumnya menjadi paragraph deskripsi yang padu. Siswa harus pandai dalam mengolah bahasa, memparafrasekan kata ataupun kalimat hingga menjadi paragraph yang runtut dan padu. Pada tahapan ini semua data yang telah dikumpulkan melalui pertanyaan yang telah dituliskan boleh dimasukkan semuanya boleh juga mereduksi data.

Uraian tersebut merupakan alur pembelajaran yang telah dilakukan dalam penerapan Inquiry Learning pada siswa kelas 6 SD N 2 Cangakan, Karanganyar. Dalam proses pembelajaran ini siswa selalu membimging dan mengarahkan terkait apa yang sedang dikerjakan oleh siswa. Guru yang bertindak sebagai fasiliator dalam pembelajaran ini harus semaksimal mungkin menghidupkan pengetahuan siswa, keaktifan siswa, dan kekreatifan siswa melalui pembelajan ini.

\section{HASIL KEMAMPUAN}

\section{Bentuk karangan}

Karangan deskripsi pada intinya mengajak pembaca seolah-olah mngalami sendri, merasakan sendiri benar-benar masuk ke dalam cerita yang dibacakan. Bentul karangan deskripsi tidak dalam penulisan ini dapat berbentuk formal ataupun nonformal. pemilihan bahasa yang tepat harus dilakukan agar karangan tidak terkesan seperti cerita fiksi. Penilaian terhadap bentuk karangan dapat dilihat sebagai berikut.

$$
\begin{aligned}
: M & =\frac{\sum F X}{N} \\
& =\frac{69}{21} \\
& =3.28
\end{aligned}
$$

Penilaian di atas menunjukkan bahwa pada aspek bentuk karangan, penilaian dapat dikatakan baik. Karangan deskripsi tidak harus menggunakan bahasa formal yang terlalu ilmiah, sebab di sini penulis diajak untuk bercerita sehingga pemilihan bahasa non formal yang tepat perlu diperhatikan. Perhitungan terhadap bentuk karangan dapat dilihat sebagai berikut.

1. Jagung termasuk tumbuhan penghasil karbohidrat.

2. Cara pisang berkembang biak dengan menanam tunas pisang.

Kutipan di atas merupakan contoh bentuk karangan formal dalam karangan deskripsi siswa. Dalam kutipan tersebut terlihat jelas bahwa bahasa yang digunakan oleh siswa termasuk dalam bahasa formal dan mendekati bahasa 
ilmiah. Dengan adanya latihan ini juga dapat digunakan untuk melatih siswa dalam menulis karangan ilmiah.

\section{Isi materi}

Aspek penilaian pada isi materi ini difokuskan pada fakta-fakta hasil pengamatan siswa. Pada aspek penilaian ini yang dinilai adalah kelangkapan isi pada teks deskripsi yang ditulis oleh siswa. Perhitungan penilaian pada aspek isi materi dapat dilihat sebagai berikut.

$$
\begin{aligned}
M & =\frac{\sum F X}{N} \\
& =\frac{72}{21} \\
& =3.42
\end{aligned}
$$

Hasil perhitungan di atas menunjukkan bahwa kemampuan siswa dalam menuliskan fakta terkait fenomena yang diamati dapat dikatakan baik. Hal ini terlihat bahwa hasil rata-rata yang diperoleh menunjukkan pada angka 3.23. siswa telah mampu dalam menuliskan atau mendeskripsikan objek yang diamati mulai dari jenis tanaman, cara berkembang biak, hingga manfaat dari tanaman tersebut. Misalnya dapat dilihat pada kutipan di bawah ini.

1. Daun Jambu biji dapat dijadikan obat diare dan sakit gigi.

2. Pepaya berfungsi untuk menyembuhkan sariawan.

Kutipan di atas menunjukkan bahwa siswa telah mampu untuk mendeskripsikan fakta dari sebuah benda yang diamati meskipun dalam kutipan tersebut masih terdapat kesalahan dalam penyusunan dan pemilihan kata ataupun kalimat. Pada kutipan satu terlihat bahwa siswa menjelaskan manfaat dari daun biji. Sebagian orang beranggapan bahwa daun jambu biji dapat digunakan sebagai obat untuk mengobati diare dan sakit gigi. Sedangkan pada kutipan dua, siswa ingin menyampaikan bahwa salah satu manfaat dari buah pepaya adalah dapat digunakan sebagai obat sariawan. Dari kedua kutipan tersebut dapat dipahami bahwa siswa telah mampu menuliskan fakta dari suatu permasalahan yang dihadapi. Akan tetapi juga terdapat beberapa tulisan yang tidak sesuai dengan fakta.

Pohon pisang ditanam dengan cara ditancapkan ditanah.

Dalam kutipan tersebut tampak bahwa siswa menuliskan salah satu cara pisang berkembang biak adalah dengan menancapkan pohon pisang ke

PiJIES: Pedagogik Journal of Islamic Elementary School 
dalam tanah. Padahal cara perkembangbiakan pohon pisang tidak dengan menancapkan pohon pisang ke dalam tanah. Pisang dapat berkembang biak dengan cara menanam tunas pisang yang tumbuh di sekitar pohon pisang. Tunas pisang tersebut dapat diambil kemudian ditanam di posisi yang berbeda dengan posisi awal.

\section{Ejaan}

Penilaian pada aspek ejaan dan tanda baca mencangkup pada penggunaan tanda baca yang digunakan oleh siswa. Penggunaan tanda baca secara tepat akan menambah poin penilaian. Sebaliknya, penggunaan ejaan dan tanda baca yang kurang tepat berpengaruh pada kurangnya peniaian terhadap aspek ejaan dan tanda baca. Hasil perhitungan pada aspek tanda baca dan ejaan dapat dilihat melalui perhitungan berikutini.

$$
\begin{aligned}
M & =\frac{\sum F X}{N} \\
& =\frac{63}{21} \\
& =3
\end{aligned}
$$

Hasil di atas merupakan nilai rata-rata dari karangan deskripsi siswa pada aspek ejaan. Pada nilai di atas belum dapat dikatakan memenuhi kriteria yang diharapkan karena nilai siswa masih tergolong cukup. Hal ini dibuktikan dengan hasil akhir yang hanya memenuhi rata-rata 3.2. beberapa yang menyebabkan hasil karangan pada aspek ejaan belum dikatakan sempurna karena masih terdapat banyak kesalahan pada aspek ejaan. Penggunaan ejaan dan tanda baca yang tepat dalam sebuah karangan sangat diperlukan dengan tujuan agar karangan dapat mudah dipahami. Beberapa kesalahan yang dibuat oleh siswa dapat dilihat sebagai berikut.

1. dondong termasuk tumbuhan dikotil.

2. Ciri -ciri tumbuhan jagung yaitu, bijinya berkeping satu, akarnya berupa serabut, memiliki daun tunggal, dan batangnya tidak bercabang.

Kutipan di atas merupakan bentuk kesalahan berbahasa yang terdapat pada karangan deskripsi siswa. Pada kutipan satu kesalahan ejaan terlihat pada penggunaan huruf kapital di awal kalimat. Penggunaan huruf di awal kalimat, harus ditulis kapital. Namun pada kutipan tersebut tidak ditulis sedemikian, sehingga termasuk dalam kesalahan ejaan. Berbeda dengan kutipan nomor dua, pada kutipan tersebut kesalahan terdapat pada penggunaan tanda hubung (-) dan koma (,). Pada penulisan kata ciri-ciri 
tersebut tanda hubung tidak dihubungkan dengan kata awal dan dipisah dengan kata tersebut. Penggunaan tanda koma pada penulisan yaitu juga termasuk kesalahan ejaan. Untuk menyebutkan, seharusnya menggunakan tanda titik dua (:) jika kalimat tersebut dilanjutkan. Namun jika pada kalimat ingin dipisah dan ditulis dengan poin, maka pada kata yaitu harus diakhiri dengan tanda baca titik (.) Adapun pembenaran dari kutipan tersebut dapat dilihat sebagai berikut.

1. Dondong termasuk tumbuhan dikotil.

2. Ciri-ciri tumbuhan jagung yaitu: bijinya berkeping satu, akarnya berupa serabut, memiliki daun tunggal, dan batangnya tidak bercabang.

\section{Tata Bahasa}

Penilaian pada aspek tata bahasa mencakup bagaimana kalimat yang ditulis siswa mudah dipahami, penggunaan struktur kalimat (SPOK), dll. Penilaian pada aspek lebih lebih menekankan pada penggunaan bahasa sesuai dengan PUEBI yang digunakan oleh siswa. Beberapa hasil karangan siswa masih jauh dari kata sempurna. Hal tersebut dapat dilihat melalui perhitungan berikut ini.

$$
\begin{aligned}
M & =\frac{\sum F X}{N} \\
& =\frac{62}{21} \\
& =2.95
\end{aligned}
$$

Pada aspek penilaian tata bahasa, karangan siswa dapat dikatakan dalam kategori cukup. Hal ini terlihat dari perhitungan rata-rata di atas yang menunjukkan nilai akhir sebesar 2.95. pemilihan kosa kata siswa dalam menuliskan deskripsi masih terpengaruh oleh bahasa lisan. Hal ini menyebabkan penilaian pada aspek ini berkurang. Siswa masih belum bisa membedakan penggunaan kata yang tepat dalam penulisan karangan. Hal ini dapat dilihat pada kutipan berikut ini.

1. Mangga itu batangnya bercabang.

2. Juga manfaat daun pepaya untuk membuat jamu.

3. Buah pisang dapat dimakan manusia dan makanan monyet dan batangnya dapat digunakan dalang dalam pertunjukan wayang.

4. Jambu batangnya bercabang. 
Beberapa kutipan di atas menunjukkan bahwa penulisan siswa masih jauh dari yang diharapkan. Hal ini dikarenakan siswa belum menerapkan penggunaan tata bahasa yang sesuai dengan kaidah kebahasaan yang baik dan benar. Pada kutipan satu di atas menunjukkan bahwa dalam kutipan tersebut siswa menulis dengan bahasa lisan pada karangan ilmiah. Seharusnya hal tersebut dihindari oleh penulis agar tulisan yang disampaikan jelas dan mudah untuk dipahami. Adanya kata itu yang merujuk pada pohon mangga tersebut membuat kalimat menjadi bahasa lisan. Untuk memperbaiki kalimat tersebut perlu membuang kata itu, karena dalam kalimat tersebut telah terdapat acuan. Pada kutipan empat juga terdapat kesalahan yang sama, dalam penggunaan acuan. Penggunaan acuan nya pada kalimat tersebut, yang mengacu pada jambu biji yang terdapat pada satu kalimat dapat dikatakan sebagai kesalahan dalam tata berbahasa.

Kesalahan tata bahasa pada kutipan dua terdapat pada penggunaan konjungsi di awal kalimat. Konjungsi yang pada umumnya digunakan sebagai kalimat penghubung tidak boelh digunakan di awal kalimat. Pada kutipan tersebut penggunaan konjungsi terdapat pada kata juga yang digunakan untuk menghubungkan kalimat awal dengan kalimat selanjutnya. Untuk membuat agar kalimat tersebut mudah dipahami, dapat merubah susunan kalimat ataupun menggabungkan kedua kalimat menjadi satu. Sama dengan data dua, pada data tiga juga terdapat kesalahan tata bahasa dalam penggunaan konjungsi. Pada data empat, terjadi penggunaan konjungsi dan yang berlebihan dalam kalimat tersebut. Kalimat tersebut dapat diperbaiki dengan membuang beberapa konjungsi dan menggabungkan dengan tanda koma.

1. Mangga memiliki batang yang bercabang.

2. daun pepaya juga dapat dimanfaatkan untuk membuat jamu.

3. Buah pisang dapat dimakan manusia, makanan monyet dan batangnya dapat digunakan dalang dalam pertunjukan wayang.

4. Batang pohon jambu bercabang.

\section{Gaya penulisan}

Gaya penulisan yang dinilai dalam aspek ini adalah ketepatan siswa dalam menggunakan pilihan kata atau diksi. Gaya penulisan juga menjadi aspek penilaian karena mempengaruhi isi cerita atau laporan yang disampaiakn. Pemilihan kosa kata yang pas dan tepat membuat karangan menjadi semakin bernilai tinggi. Namun semakin banyak kesalahan dalam pemilihan kata menjadikan karangan semakin bernilai rendah. Hasil perhitungan pada aspek gaya penulisan dapat dilihat sebagai berikut. 
$: M=\frac{\sum F X}{N}$

$$
=\frac{59}{21}
$$$$
=2.80
$$

Penilaian di atas menunjukkan bahwa hasil yang dikerjakan oleh siswa dalam aspek kosa kata belum memenuhi standar keriteria, karena masih tegolong rendah dari aspek-aspek yang lain. Hal ini terlihat dalam hasil perhitungan di atas yang menunjukkan angka 2.80, yang menunjukkan kategori cukup. Dalam pemilihan kosa kata, siswa belum terampil dalam pemilihan kata. Hal tersebut dapat dilihat dalam kutipan berikut ini.

1. Jambu biji juga bisa di buat jus

2. Dan mangga mempunyai vitamin $\mathrm{C}$.

Beberapa kutipan di atas menunjukkan adanya kesalahan pemilihan kosa kata dalam karangan siswa. Pada kutipan satu terlihat bahwa siswa belum mampu untuk membedakan kata bisa dan dapat. Kata dapat lebih pas dan cocok untuk menggantikan kata bisa dan kata mengandung lebih pas dan cocok dalam menggantikan kata mempunyai. Selain itu, pada kalimat satu juga terdapat kesalahan dalam bentukan kata di pisah. Penggunaan imbuhan di dipisah hanya digunakan untuk menunjukkan tempat. Sedangkan untuk awalan harus digabung. Sedangkan kesalahan pada kutipan dua terdapat pada penggunaan konjungsi di awal kalimat, yang di tandai dengan konjungsi dan. sebagai bentKalimat tersebut dapat diperbaiki seperti berikut ini.

\section{Jambu biji juga dapat dibuat jus}

2. mangga mengandung vitamin $C$.

\section{Perhitungan Rata-Rata}

Setelah dilakukan penjabaran penilaian dari masing-masing aspek, langkah terakhir yaitu melakukan perhitungan terhadap hasil akhir yang diperoleh. Hasil ini dapat dijadikan patokan terhadap kategori nilai yang didapat dari penulisan karangan siswa. Hasil rata-rata tersebut dapat dilihat sebagai berikut.

$$
\begin{aligned}
\text { rata }- \text { rata } & =\frac{\text { nilai total }}{\text { jumlah siswa }} \\
& =\frac{1521}{21} \\
& =72.4
\end{aligned}
$$

PiJIES: Pedagogik Journal of Islamic Elementary School 
Hasil di atas menunjukkan bahwa nilai akhir rata-rata keterampilan menulis teks deskripsi pada tanaman dikotil dan monokotil, dengan menggunakan metode pembelajaran Inquiry learning dalam kategori baik. Hasil akhir menunjukkan nilai sebesar 72.4. dalam hal ini dapat dikatakan bahwa penerapan metode pembelajaran Inquiry learning pada pembelajaran tematik satu dikatakan berhasil. Siswa mampu mendeskripsikan tanamantanam di sekitar lingkungan sekolah, berdasarkan fakta yang diperoleh baik melalui pengalaman ataupun pembacaan buku. Meskipun demikian dalam hal tata tulisan perlu lebih diperhatikan. sebab dalam penilaian peraspek di atas dapat dilihat bahwa dalam ejaan dan tanda baca, gaya penulisan dan tata bahasa masih dalam kategori cukup serta perlu banyak pembenahan.

\section{PENUTUP}

Metode pembelajaran Inquiry Learning, merupakan satu dari sekian metode pembelajaran yang dapat digunakan sebagai metode pembelajaran bagi guru. Metode ini pada prinsipnya mengajak siswa untuk aktif, kreatif dan mampu menemukan hal-hal baru berdasarkan pengalaman yang nyata. Penerapan metode ini dalam pembelajaran tematik satu di SD N 2 Cangakan, Karanganyar dilakukan melalui beberapa tahapan 5M. tahapan tersebut mendukung siswa untuk aktif dan kreatif dalam menemukan hal-hal baru beradsarkan pengalaman yang ia temui. Hasil dari penerapan Metode pembelajaran Inquiry Learning, ini menunjukkan pada predikat baik. Hasil akhir terlihat dari rata-rata nilai siswa yang berjumlah 72.61. meskipun penerapan metode ini menunjukkan predikat baik, namun guru perlu memperhatikan kualitas tulisan siswa yang masih jauh dari kesempurnaan. Masih banyak ditemukan kesalahan dalam penyusunan kalimat yang ditulis oleh siswa, sehingga hal tersebut perlu diperbaiki.

\section{DAFTAR PUSTAKA}

Antari, L. (2015). Penggunaan Bahan Ajar Tematik Pembagian untuk Meningkatkan Hasil Belajar di Kelas IIA Mi Ahliyah II Palembang. Aksioma, 4(2), 22-29.

Aqillah, N., \& Ifa, R. N. (2018). The Implementation of Jigsaw Learning in Improving VII Grade Students' Achievement MTsN Kedungharjo Mantingan for Sejarah Kebudayaan Islam Subject. Educan: Jurnal Pendidikan Islam, 2(1), 40-54.

Devi, P. C., Yusak, H., \& Widyatmike, G. M. (2018). Pengembangan Bahan Ajar Menulis Teks Prosedur Kompleks dengan Model Pembelajaran Discovery Learning Menggunakan Media Audio Visual (Video) di Kelas XI SMA Negeri 1 Samarinda. Diglosia, 1(2), 101-112.

Hanafiah, \& Suhana. (2010). Konsep Strategi Pembelajaran. Bandung: PT Refika.

Hariyanto, P. (2018). Ketidakefektifan Kalimat dalam Tulisan Guru SD 
(Ineffective Sentence In Elementary School Teachers' Writings). Metalingua, 16(1), 63-78.

Hasanah, D. U., Ferdian, A., \& Afrizal, M. (2019). Kemampuan Menulis Cerpen Mahasiswa Tadris Bahasa Indonesia Iain Surakarta Melalui Penerapan Metode Berpikir Kreatif Cara Spiritualisme Kritis. Alayasastra, 15(1), 4559.

Mulyati, Y., \& dkk., (2018). Hakikat Bahasa (Modul). Jakarta: Universitas Terbuka.

Oktaria, D., Andayani, \& Kundharu, S. (2017). Penguasaan Kalimat Efektif Sebagai Kunci Peningkatan Keterampilan Menulis Eksposisi. Metalingua, 15(2), 165-177.

Patmawati. (2018). Metode Experiential Learning dalam Pembelajaran Keterampilan Menulis Deskriptif pada Mahasiswa Pendidikan Guru Sekolah Dasar. PiJIES: Pedagogik Journal of Islamic Elementary School, 1(1), 1-10.

Purwanti, T. (2017). Peningkatan Keterampilan Menulis Paragraf Deskripsi Menggunakan Media Kartu Gambar pada Siswa Kelas IV SD Negeri 2 Geneng Jepara.Jurnal Pendidikan Bahasa Indonesia, 5(2), 100-105.

Saharsa, U., \& Muhammad, Qaddafi, B. (2018). Efektivitas Penerapan Model Pembelajaran Problem Based Learning Berbantuan Video Based Laboratory Terhadap Peningkatan Pemahaman Konsep Fisika. Jurnal Pendidikan Fisika, 6(2), 57-64.

Siregar, E. S. (2018). Penerapan Strategi Pembelajaran Think Talk Write ( TTW ) dalam Meningkatan Keterampilan Menulis Teks Eksposisi Analitis pada Peserta Didik. Journal of Education Action Reasearch, 2(3), 285289.

Sudiharto. (2017). Peningkatan Kemampuan Menyusun Kalimat Percakapan dengan Menggunakan Media Gambar Siswa Kelas V Semester 2 SD Negeri 1 Pekalongan Kec Batealit Kabupaten Jepara. Jurnal Pendidikan Bahasa Indonesia, 5(1), 83-99.

Sukardi. (2018). Pengaruh Media Gambar Fotografi Terhadap Kemampuan Menulis Deskripsi Siswa Kelas XI SMA Muhammadiyah 23 Jakarta Timur. Imajeri, 1(1), 34-44. 